\title{
Establishment of Bacterial Antagonists of Erwinia amylovora on Pear and Apple Blossoms as Influenced by Inoculum Preparation
}

\author{
V. O. Stockwell, K. B. Johnson, and J. E. Loper
}

First and third authors: USDA-ARS Horticultural Crops Research Laboratory, Corvallis, OR 97330; and second author: Department of Botany and Plant Pathology, Oregon State University, Corvallis 97331-2902.

Accepted for publication 13 February 1998.

\begin{abstract}
Stockwell, V. O., Johnson, K. B., and Loper, J. E. 1998. Establishment of bacterial antagonists of Erwinia amylovora on pear and apple blossoms as influenced by inoculum preparation. Phytopathology 88:506-513.

The influence of inoculum preparation on the establishment of bacterial antagonists that suppress fire blight and Erwinia amylovora on blossoms was evaluated. Aqueous suspensions of Pseudomonas fluorescens A506, E. herbicola C9-1R, or E. amylovora $153 \mathrm{~N}$ were prepared from cells harvested from the surface of an agar medium or from cells that were lyophilized after culture under similar conditions. Bacterial suspensions $\left(1 \times 10^{8} \mathrm{CFU} / \mathrm{ml}\right)$ were sprayed on pear and apple trees at $50 \%$ bloom near midday. The incidence of recovery (proportion of blossoms containing detectable populations) and the population sizes of the bacteria on individual blossoms with detectable populations were followed over a period of several days. Fluorescent microspheres $(1 \mu \mathrm{m}$ in diame-
\end{abstract}

ABSTRACT

Fire blight, caused by Erwinia amylovora, is a serious disease of pear trees and is of increasing economic importance on apple, because the spectrum of commercial cultivars has expanded from the relatively resistant 'Red Delicious' to cultivars more susceptible to fire blight (e.g., 'Braeburn', 'Fuji', 'Gala', and 'Jonagold') $(22,29)$. Severe epidemics of fire blight occur when rain or heavy dew and temperatures exceeding $15^{\circ} \mathrm{C}$ are coincident with full bloom of pear or apple (31). Under these conditions, E. amylovora colonizes the stigmatic surfaces of blossoms, where it establishes large population sizes before infecting the host $(6,30,36)$. Pear and apple growers in the United States apply antibiotics during bloom to suppress growth and infection by the pathogen. Streptomycin has been the most effective antibiotic to control fire blight, but streptomycin-resistant isolates of E. amylovora are now prevalent in many regions of the United States (19-21). Streptomycin resistance in indigenous populations of E. amylovora has increased the risk of fire blight epidemics, thereby increasing the need for alternative control measures.

If applied to blossoms at early to mid-bloom, the biological control agents Pseudomonas fluorescens A506 (PfA506) and E. herbicola $\mathrm{C} 9-1$ (EhC9-1) can proliferate on pear and apple stigmas (11, $12,15,17,23,28,33)$ and exclude the pathogen from infection sites $(6$, $12,15,32,33)$. The incidence of fire blight on blossoms was reduced by about $60 \%$ with two applications of bacterial antagonists in experimental plots in the Pacific Northwest $(12,23)$ and California $(15,17)$. The efficacy of biological control approached or equaled levels obtained with chemical control in many of the field trials (17).

Corresponding author: V. O. Stockwell; E-mail address: stockwev@bcc.orst.edu

Publication no. P-1998-0330-01R

This article is in the public domain and not copyrightable. It may be freely reprinted with customary crediting of the source. The American Phytopathological Society, 1998. ter) were added to sprays at a concentration of $1 \times 10^{7}$ microspheres per $\mathrm{ml}$ to mark blossoms that were open during application of bacteria. After dilution-plating, the stigmas and styles of each blossom were examined for the presence of microspheres with an epifluorescence microscope. In three of five trials, bacteria applied as suspensions of lyophilized cells were recovered from a greater proportion of blossoms than bacterial cells harvested directly from culture media. Every blossom harvested within 6 days after spraying had microspheres present on the surfaces of the styles and stigmas; thus, lack of establishment of detectable populations, rather than escape of blossoms from spray inoculation, accounted for the differences in proportion of blossoms colonized by the different preparations of bacteria. The use of lyophilized cells in field trials decreased variability in the establishment of bacteria on blossoms.

Additional keywords: biological control.

Biological control is most effective against fire blight if the antagonists are established in high populations prior to the introduction of E. amylovora to blossoms $(23,33)$. Under field conditions, Johnson et al. (12) found that early establishment of populations exceeding $10^{5}$ CFU per blossom of PfA506 and EhC9-1 on pear blossoms suppressed establishment and growth of E. amylovora, thereby decreasing disease incidence. In field plots, population sizes established by PfA506 or EhC9-1 on blossoms averaged $10^{5}$ to $10^{6} \mathrm{CFU}$ per blossom; however, only 50 to $70 \%$ of the treated blossoms had detectable populations of the antagonists (28). The percentage of blossoms with detectable populations of PfA506 or EhC9-1 correlated inversely with the percentage of diseased blossoms (12,23). Because consistent and early colonization of stigmas by an antagonist is required to suppress fire blight, improvements in the initial establishment of $P$. fluorescens or E. herbicola on blossoms should enhance biological control of this disease.

Establishment of bacterial antagonists on aerial plant surfaces is a challenge in biological control. Antagonists that suppress disease in laboratory or greenhouse experiments may fail to establish threshold populations required for biological control in the field. In field trials, inoculum often consists of bacterial cells grown on solid media, harvested, resuspended, and sprayed onto plant surfaces. Aerial surfaces of plants can be inhospitable to bacterial growth, because they are exposed to UV light, rapid changes in temperature and water availability, and coincident fluctuations in osmotic potential and nutrient availability (3). For example, populations of Pseudomonas spp. applied to aerial surfaces of plants under hot and dry conditions may decrease rapidly to below the detection limit $(1,2,8,13,14,24,34,35)$. Bacterial cells unable to survive the transition from a growth medium to an exposed plant surface do not establish population sizes needed to suppress disease. Current formulation technology may allow for the development of commercial preparations that optimize the capacity of bacterial antagonists to survive the conditions encountered immediately up- 
on inoculation of aerial plant surfaces. For example, the process of lyophilization imposes both temperature and desiccation stresses on bacterial cells (4) and could select for cells within a population that are tolerant to those stresses. The purpose of this investigation was to compare bacterial cells harvested directly from a culture medium with lyophilized cells for their establishment on blossoms of pear and apple.

\section{MATERIALS AND METHODS}

Experimental plot design. All experiments were conducted at the Oregon State University Department of Botany and Plant Pathology Field Laboratory near Corvallis on pear and apple trees spaced $6 \mathrm{~m}$ apart. In 1993, the experiments were conducted in a block of 50 34-year-old 'Rome Beauty' apple trees, in a block of 70 17-year-old 'Golden Delicious' apple trees, and in a block of 75 17-year-old 'Bosc' pear trees. In 1994, experiments were conducted in the block of 'Rome Beauty' apple trees used in 1993 and in a block of 90 30-year-old 'Bartlett' pear trees. Treatments were applied in a completely randomized block design with at least three single-tree replications of each treatment.

Bacterial strains. PfA506, obtained from S. E. Lindow (Department of Plant and Microbial Biology, University of California, Berkeley), is a rifampicin-resistant $(100 \mu \mathrm{g} / \mathrm{ml})$ derivative of an epiphyte recovered from pear in California (15). EhC9-1, obtained from C. A. Ishimaru (Department of Bioagricultural Sciences and Pest Management, Colorado State University, Fort Collins), was isolated from an apple tree in Michigan (10). EhC9-1R is a spontaneous rifampicin-resistant $(100 \mu \mathrm{g} / \mathrm{ml})$ derivative that is similar to the parental strain in growth rate and herbicolin production (10). E. amylovora strain 153 was isolated from a fire blight canker on apple in eastern Oregon. E. amylovora strain 153N (Ea153N) is a spontaneous nalidixic acid-resistant $(100 \mu \mathrm{g} / \mathrm{ml})$ derivative of strain Ea153. Pathogenicity of Ea153N was verified in previous field experiments $(12,23)$. All bacterial strains were stored in nutrient broth containing $15 \%$ glycerol at $-80^{\circ} \mathrm{C}$ until use.

Inoculum preparation. Bacteria were cultured for 5 days at $20^{\circ} \mathrm{C}$ on nutrient agar (Difco Laboratories, Detroit) amended with $1 \%$ (wt/vol) glycerol. To prevent contamination, rifampicin (50 $\mu \mathrm{g} / \mathrm{ml}$ ) was added to the medium for the culture of PfA506 or EhC9-1R, and nalidixic acid $(50 \mu \mathrm{g} / \mathrm{ml})$ was added for the culture of Ea153N. Lyophilized inocula were prepared from bacterial cells harvested from the agar surface. The bacterial mass was weighed and mixed 2:1 (wt/vol) with a cryoprotectant slurry of $38 \%$ powdered milk and $2 \%$ xanthan gum before lyophilization as described by Johnson et al. (11). Lyophilized bacterial preparations were ground to a fine powder, passed through a $0.3-\mathrm{mm}$ mesh screen, and stored at $-20^{\circ} \mathrm{C}$. Titer of the lyophilized preparations was determined by dilution-plating and ranged from $1 \times 10^{10}$ to $1 \times 10^{11} \mathrm{CFU} / \mathrm{g}$. Fresh-cell inocula consisted of bacteria that were harvested from 5-day-old lawns and suspended in $10 \mathrm{mM}$ potassium phosphate buffer, $\mathrm{pH}$ 7.0. The bacterial suspensions were adjusted to 0.1 optical density at $600 \mathrm{~nm}$ using a spectrophotometer (Spectronic 20; Milton Roy Co., Rochester NY) to approximate a cell density of $1 \times 10^{8} \mathrm{CFU} / \mathrm{ml}$.

Application of bacteria. Bacteria were applied to trees at $50 \%$ bloom on 12 April 1993 ('Bosc' pear), 20 April 1993 ('Golden Delicious' apple), 29 April 1993 ('Rome Beauty' apple), 10 April 1994 ('Bartlett' pear), and 24 April 1994 ('Rome Beauty' apple). All treatments were made at noon, except in the 'Golden Delicious' plot, in which they were applied at 9:30 a.m. Fresh-cell bacterial suspensions were made within $1 \mathrm{~h}$ before inoculation. At the same time, lyophilized antagonists were suspended in $10 \mathrm{mM}$ potassium phosphate buffer, $\mathrm{pH} 7.0$, to obtain a cell density of $1 \times 10^{8} \mathrm{CFU} / \mathrm{ml}$, which was confirmed by dilution-plating of the spray mixture. In the 1994 trials, PfA506 and EhC9-1R also were sprayed at a lower dose of $1 \times 10^{7} \mathrm{CFU} / \mathrm{ml}$. Ea153N was applied at three different inoculum doses: $1 \times 10^{8} \mathrm{CFU} / \mathrm{ml}$ on apples in $1993 ; 1 \times 10^{7} \mathrm{CFU} / \mathrm{ml}$ on pears in 1993 and 1994 and on 'Rome Beauty' apple in 1994; and $1 \times 10^{6} \mathrm{CFU} / \mathrm{ml}$ in other 1994 trials. Bacterial suspensions were sprayed until near runoff to blossom clusters with a handheld, 1-liter spray bottle. At least 75 blossom clusters on branches marked with plastic ribbon were inoculated on each tree.

Recovery of bacteria from blossoms. Open blossoms with black, mature anthers were collected 3 to $4 \mathrm{~h}$ after application of bacteria and periodically during the following week. Twenty-four ('Rome Beauty' apple, 'Golden Delicious' apple, and 'Bartlett' pear) or thirty blossoms ('Bosc' pear) were sampled from each treatment (six to eight blossoms per replicate tree) on each sampling date and placed immediately into individual wells of surface-disinfected, plastic, 12-well microtiter plates (Corning Inc., Corning, $\mathrm{NY}$ ) to avoid cross-contamination during transport to the laboratory. The stigmas and styles of each apple blossom or the pistil and nectary of each pear blossom were excised and placed into test tubes containing $1 \mathrm{ml}$ of sterile $10 \mathrm{mM}$ potassium phosphate buffer, $\mathrm{pH} 7.1$, and sonicated for $3 \mathrm{~min}$. After sonication, a 10- $\mu \mathrm{l}$ sample of the buffer in the test tube containing pistillate tissue and $10-\mu$ l samples of two sequential 100-fold dilutions of the buffer were spread onto Pseudomonas agar F (Difco Laboratories) with $50 \mu \mathrm{g}$ of cycloheximide per $\mathrm{ml}$ and $100 \mu \mathrm{g}$ of rifampicin per $\mathrm{ml}$ for selective recovery of the bacterial antagonists or CCT medium (9) containing $50 \mu \mathrm{g}$ of nalidixic acid per $\mathrm{ml}$ for recovery of the pathogen. The detection limit was $1 \times 10^{2} \mathrm{CFU}$ per blossom.

Fluorescent microspheres. Fluorescent carboxylate microspheres (Fluoresbrite YG microspheres, $1 \mu \mathrm{m}$ in diameter; Polysciences Inc., Warrington, PA) were added to bacterial suspensions at a concentration of $1 \times 10^{7}$ spheres per $\mathrm{ml}$ to mark blossoms that were open during spraying. After dilution-plating for recovery of bacteria from blossoms, $0.03 \%$ sodium azide was added to the buffer containing the blossom sample. Preserved tissue samples were stored at $4^{\circ} \mathrm{C}$. The surface of each pistil was examined with a Zeiss standard epifluorescence microscope (485-nm excitation filter, 520-nm emission filter; Carl Zeiss, Inc., Thornwood, NY) for the presence of microspheres. The Fluoresbrite YG microspheres fluoresce a yellow-green color with that filter combination. Autofluorescent microspheres are available in several colors; however, we found that microspheres containing a blue-fluorescing dye (Fluoresbrite BB microspheres, Polysciences Inc.) faded after several days of exposure to the environment and could not be seen on plant tissues.

Weather data. Weather data were recorded during each of the experiments. Relative humidity, solar radiation, and wind speed data were obtained from an AgriMet weather station (Northwest Cooperative Agricultural Weather Network, Bonneville Power Administration, and the U.S. Bureau of Reclamation, Boise, ID) located near Corvallis. Moisture events and canopy temperatures were monitored with a CR-21X micrologger (Campbell Scientific, Inc., Logan, UT). Eight leaf wetness and four temperature sensors were placed on the periphery of the canopy at a height of $1.5 \mathrm{~m}$ in a tree within the plot. Four of the leaf wetness sensors were sprayed until near runoff with a bacterial suspension, and the duration of wetness (minutes) resulting from spray inoculation was recorded. Recordings from these four sensors were averaged.

Desiccation tolerance. Aqueous suspensions of lyophilized and fresh cells of PfA506 and EhC9-1R $\left(1 \times 10^{8} \mathrm{CFU} / \mathrm{ml}\right)$ were prepared as described above. Ten-microliter samples were placed onto $1-\mathrm{cm}^{2}$ pieces of sterile filter paper (Whatman No. 1; Whatman International, Ltd., Maidstone, England). Filter papers were incubated at $20^{\circ} \mathrm{C}$ suspended over distilled water or a saturated solution of $\mathrm{NaCl}$ in sealed plastic chambers to maintain a relative humidity of 100 or $75 \%$, respectively (16). Five to seven times during a 24-h period, five replicate paper squares of each preparation were removed from the chambers, placed in $1 \mathrm{ml}$ of phosphate buffer, sonicated, and 10-fold dilutions were spread on Pseudomonas agar F. Plates were incubated for 3 days at $27^{\circ} \mathrm{C}$, and the colonies were counted. The experiment was repeated. 
Data analysis. The population size of inoculated bacterial strains on blossom surfaces in some treatments was commonly below the minimum value (100 CFU per blossom) detectable by dilutionplating. Therefore, population data were presented as two values: the incidence of recovery, indicating the proportion of blossoms from which a bacterial strain was detected, and the size of detectable populations, indicating the mean population size only on those blossoms on which bacteria were detected $(11,12,23,28)$. Taken together, the two values accurately represent the population data. Nevertheless, estimates of detectable population size presented here are not always directly comparable to population size estimates from data sets in which values from replicates below the detection limit are set at zero (17), near the detection limit (7), or at values extrapolated from the distribution of populations on replicates in which bacteria were detected $(7,26)$.

The SAS (Statistical Analysis Systems Institute, Cary, NC) General Linear Model procedure was used for statistical analysis of bacterial population data. Incidence data were arcsine square root-transformed before analysis. Fisher's protected least significant difference test $(P=0.05)$ was used to separate means. The analyzed incidence data were back-transformed and presented as percentages. Mean detectable population size and standard error of bacterial strains on individual blossoms were calculated by

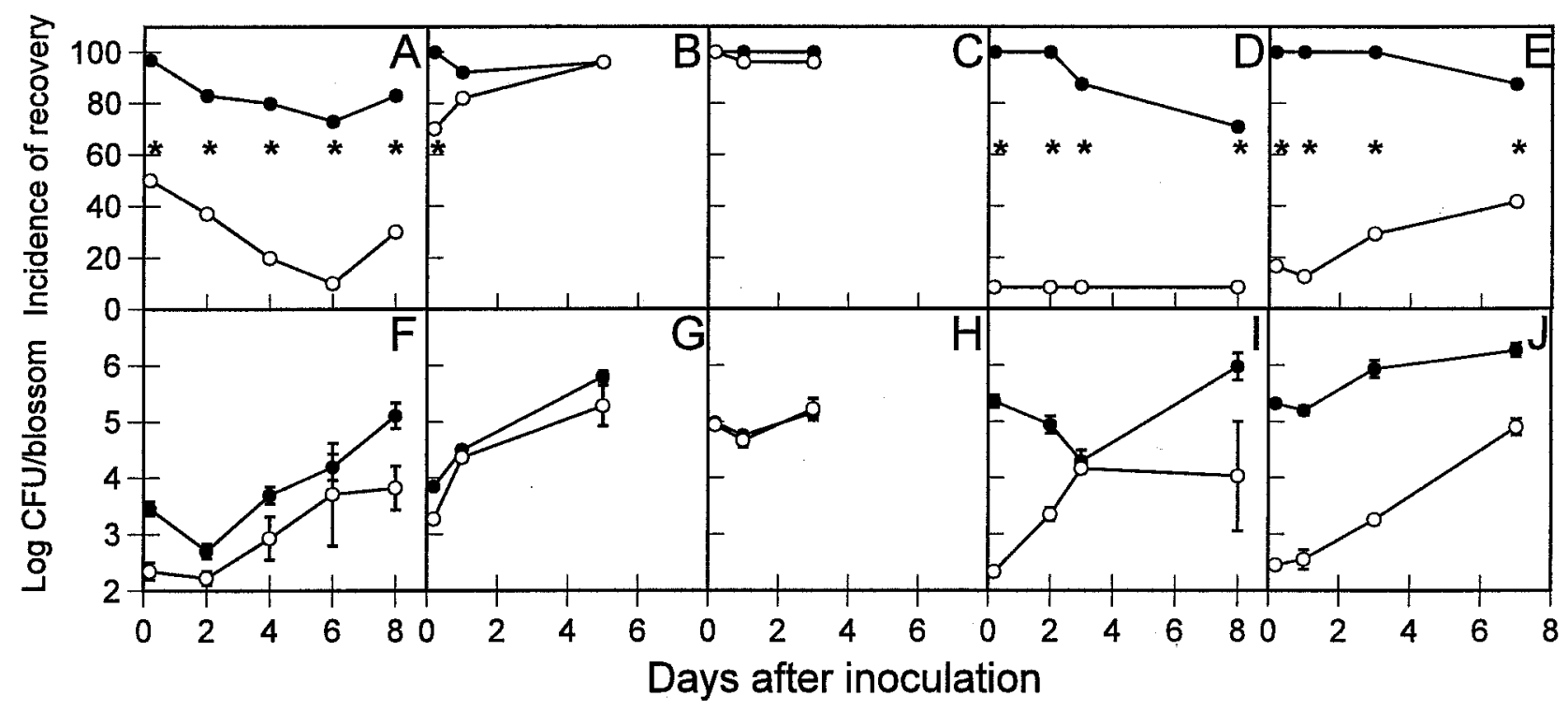

Fig. 1. Establishment of lyophilized $(\bullet)$ and fresh cell $(\bigcirc)$ preparations of Pseudomonas fluorescens A506 (PfA506) applied to near runoff at a concentration of $1 \times 10^{8} \mathrm{CFU} / \mathrm{ml}$ on blossoms of A and F, 'Bosc' pear in 1993; B and G, 'Rome Beauty' apple in 1993; C and H, 'Golden Delicious' apple in 1993; D and I, 'Bartlett' pear in 1994; and $\mathbf{E}$ and J, 'Rome Beauty' apple in 1994. A to E, Incidence of recovery of PfA506 from blossoms (i.e., the proportion of blossoms with detectable populations). A, D, and E, The asterisks indicate that treatment means of transformed incidence of recovery of $P f$ A506 differed significantly on a sampling date according to Fisher's least significant difference procedure $(P=0.05)$. F to $\mathbf{J}$, The mean detectable population size of $P f$ A506 on blossoms. Vertical bars, often obscured by the symbol, represent the standard error of the mean detectable population size.

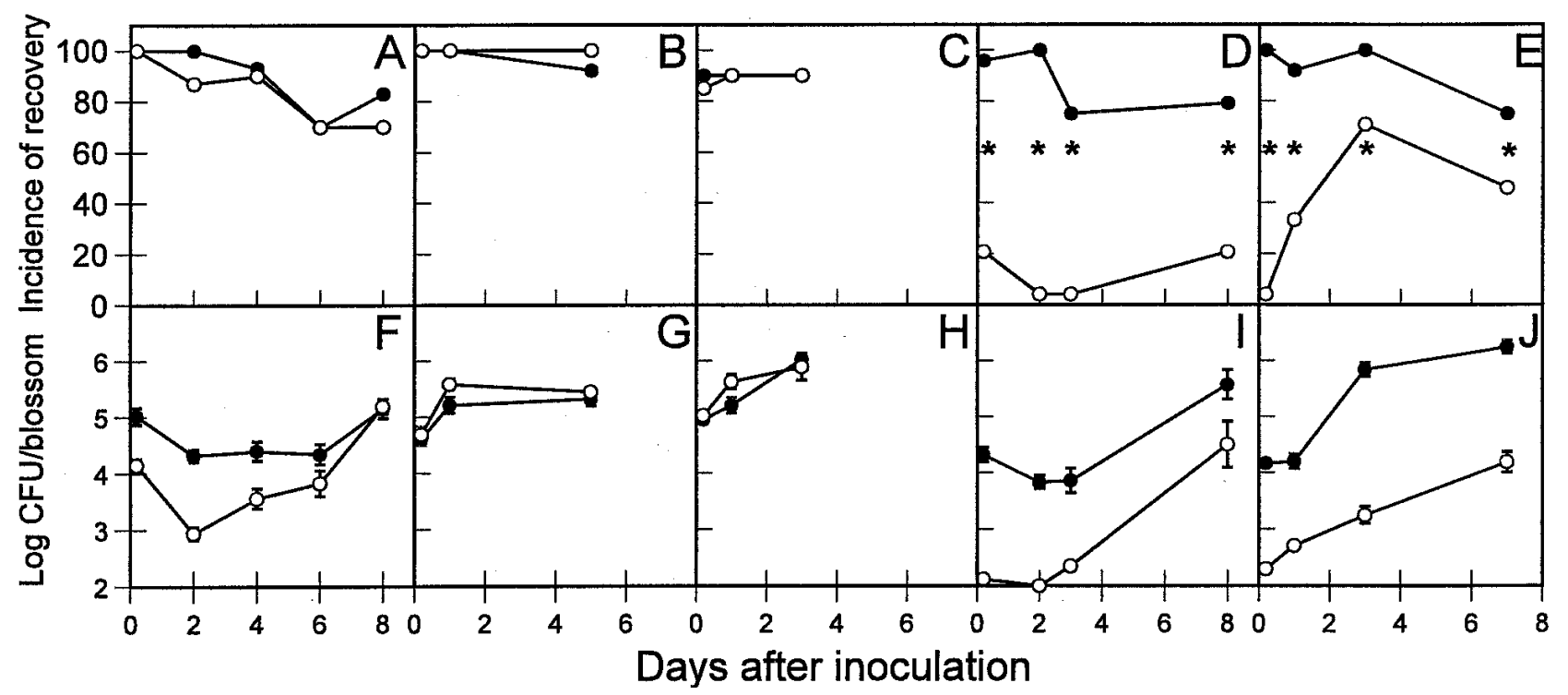

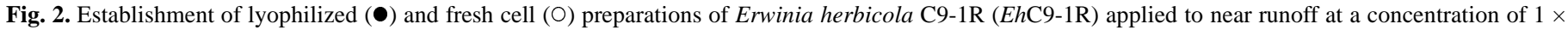

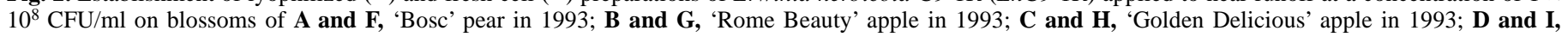

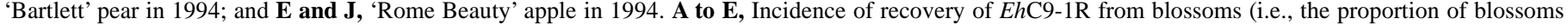

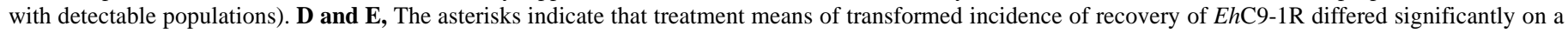

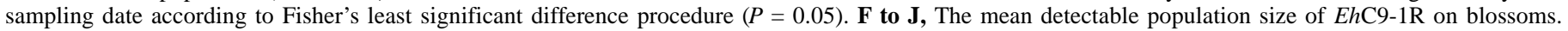
Vertical bars, often obscured by the symbol, represent the standard error of the mean detectable population size. 
averaging the logarithm (base 10) of values obtained for blossoms on which bacteria were recovered.

In the desiccation tolerance studies, bacterial strains were recovered at detectable populations from all of the filter papers sampled. The populations were log-transformed, and Fisher's protected least significant difference test $(P=0.05)$ was used to separate treatment means.

\section{RESULTS}

Establishment of PfA506. Spray inoculation of pear and apple trees at $50 \%$ bloom with a suspension of lyophilized cells of PfA506 $\left(1 \times 10^{8} \mathrm{CFU} / \mathrm{ml}\right)$ resulted in the establishment of detectable populations on 70 to $100 \%$ of apple and pear blossoms in 1993 and 1994 (Fig. 1A to E). On those blossoms on which PfA506 was detected, the mean detectable population size varied from $10^{3}$ to $10^{6} \mathrm{CFU}$ per blossom following inoculation with lyophilized cells (Fig. 1F to J). In contrast, establishment of PfA506 applied as fresh cells $\left(1 \times 10^{8} \mathrm{CFU} / \mathrm{ml}\right)$ onto blossoms was more variable. In two trials ('Rome Beauty' and 'Golden Delicious' apple in 1993), PfA506 established detectable populations on a similar proportion of blossoms when applied as fresh or lyophilized cells (Fig. 1B and C). In three trials, however, the incidence of establishment of fresh cells of PfA506 on blossoms was significantly lower compared with the lyophilized preparation (Fig. 1A, D, and E). For example, at $4 \mathrm{~h}$ after application on 'Bosc' pear in 1993, 'Bartlett' pear in 1994, and 'Rome Beauty' apple in 1994, the incidence of recovery of fresh cells of PfA506 was reduced 47, 92, and 83\%, respectively, compared with the incidence of recovery of lyophilized cells. By late bloom in each of these trials, PfA506 was recovered from a majority ( 70 to $88 \%$ ) of blossoms inoculated with lyophilized cells, but from a significantly lower proportion of blossoms inoculated with fresh cells of the bacterium. In these trials, the mean detectable population size of PfA506 on blossoms commonly was lower when inoculated as fresh cells compared with lyophilized cells of the antagonist (Fig. 1F, I, and J). In two trials in which the incidence of recovery of PfA506 was similar between inoculum preparations (Fig. 1B and C), the mean detectable population sizes also were not significantly different between treatments (Fig. $1 \mathrm{G}$ and $\mathrm{H}$ ).
In 1994 trials with 'Bartlett' pear and 'Rome Beauty' apple, PfA506 was applied at both $1 \times 10^{8} \mathrm{CFU} / \mathrm{ml}$ and $1 \times 10^{7} \mathrm{CFU} / \mathrm{ml}$. PfA506 was recovered rarely from blossoms inoculated with fresh cells at $1 \times 10^{7} \mathrm{CFU} / \mathrm{ml}$ (data not shown). When comparing the two inoculum-dose treatments on the establishment of lyophilized cells of PfA506, the mean detectable population size recovered from blossoms differed significantly for 2 days after inoculation, but incidences of recovery ( 85 to $100 \%$ of blossoms) were not significantly different (data not shown). One week after applying lyophilized cells of PfA506, the incidence of recovery and the mean detectable population sizes on blossoms were not significantly different between the two inoculum doses.

Establishment of EhC9-1R. Similar to the results obtained with PfA506, application of suspensions of lyophilized cells of EhC9-1R $\left(1 \times 10^{8} \mathrm{CFU} / \mathrm{ml}\right)$ on pear and apple trees at $50 \%$ bloom resulted in the establishment of detectable populations on 70 to $100 \%$ of blossoms sampled (Fig. 2A to E). At the first sample time, the bacterium was recovered at mean detectable population sizes of $10^{4}$ to $10^{5} \mathrm{CFU}$ per blossom from nearly all blossoms sprayed with lyophilized cells (Fig. 2F to J). In all trials except the 'Bosc' pear trial, the mean detectable population size of EhC9-1R from lyophilized inocula increased 10- to 100-fold during bloom.

The establishment of EhC9-1R on blossoms inoculated with fresh cells at $1 \times 10^{8} \mathrm{CFU} / \mathrm{ml}$ was variable. In 1993 trials, there was no significant difference in the incidence of recovery of EhC9-1R from blossoms treated with fresh or lyophilized inocula (Fig. 2A to C). The mean detectable population size of EhC9-1R applied as fresh-cell inoculum was not significantly different than the mean detectable population sizes recovered from 'Rome Beauty' and 'Golden Delicious' apple blossoms treated with lyophilized preparations of the bacterium in 1993 (Fig. 2G and H). The mean detectable population size of EhC9-1R recovered during the first three sample times from 'Bosc' pear blossoms in 1993 treated with the fresh cells, however, was significantly lower than the mean detectable population size recovered from blossoms treated with the lyophilized cells (Fig. 2F), although mean detectable population sizes were not significantly different in later samples. Inoculum preparation had a greater effect on the establishment of EhC9-1R on blossoms in 1994 trials than in 1993 trials. Although similar numbers of bacterial cells were sprayed onto blossoms regardless

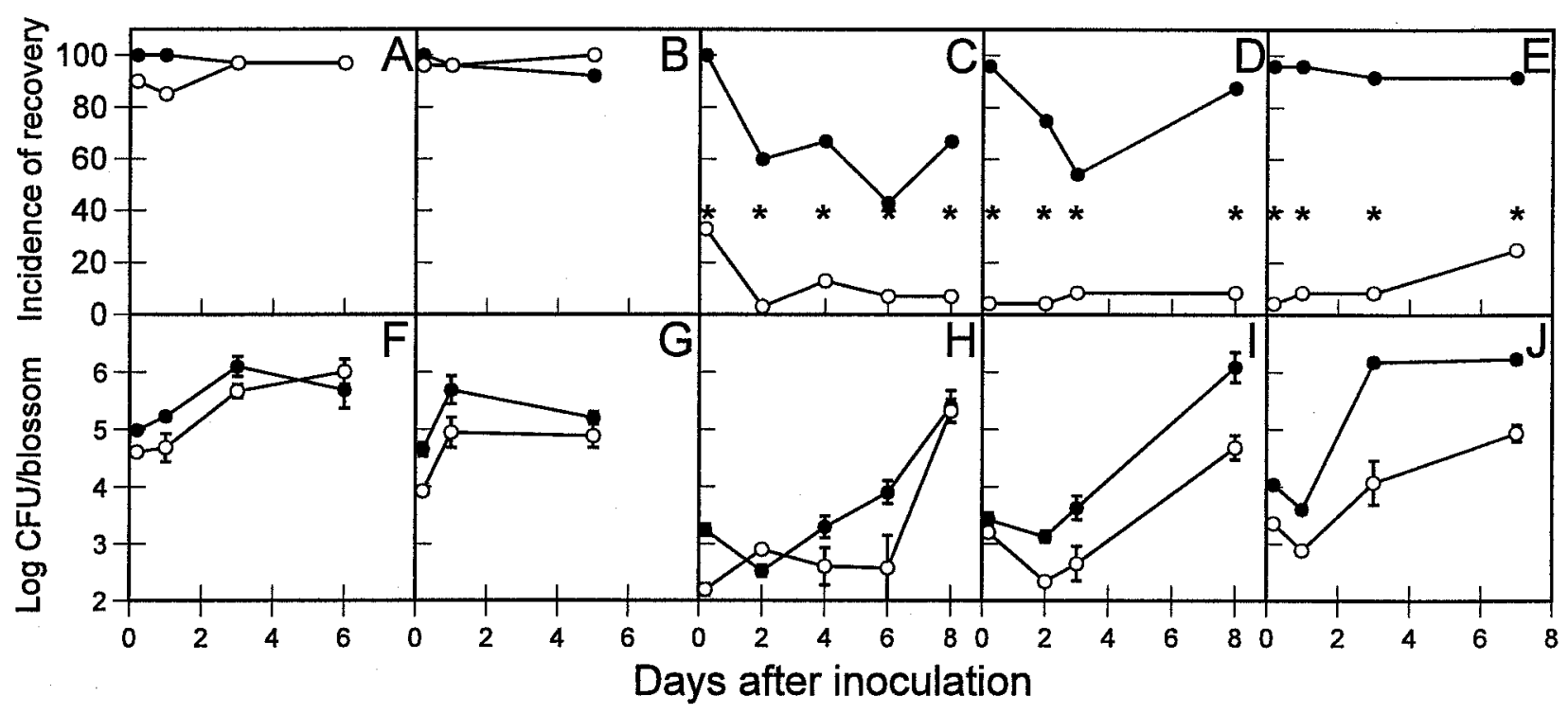

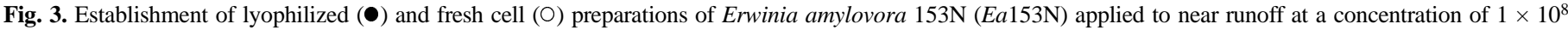

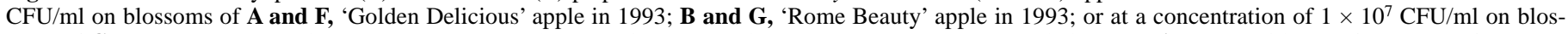

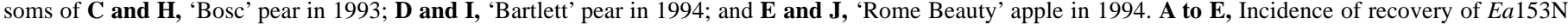

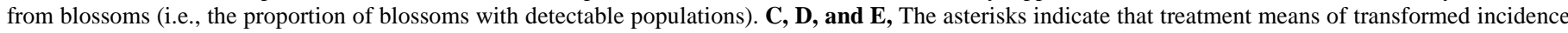

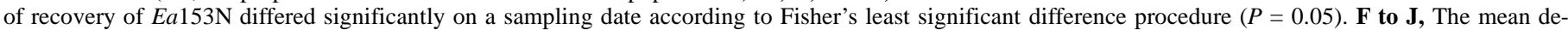
tectable population size of Ea153N on blossoms. Vertical bars, often obscured by the symbol, represent the standard error of the mean detectable population size. 
of the inoculum preparation method, few fresh cells survived on blossom surfaces until the first sampling time (4 h after application) in 1994 trials. EhC9-1R was recovered at population sizes near the detection limit $\left(1 \times 10^{2} \mathrm{CFU}\right.$ per blossom) from only 5 to $35 \%$ of the blossoms sampled within 2 days after application of the fresh-cell preparation (Fig. 2D, E, I, and J). By late bloom in 1994, detectable fresh-cell populations averaged $10^{4} \mathrm{CFU}$ per blossom on 20 to $45 \%$ of the blossoms sampled.

Lyophilized cells of EhC9-1R applied in 1994 at $1 \times 10^{7}$ CFU/ml established mean detectable populations of $10^{2}$ to $10^{3} \mathrm{CFU}$ per blossom (data not shown), which was significantly lower than mean detectable populations established when blossoms were sprayed with lyophilized cells at $1 \times 10^{8} \mathrm{CFU} / \mathrm{ml}$ (Fig. 2I and J). One week after inoculation, the mean detectable population size of EhC9-1R applied as lyophilized cells at $1 \times 10^{7} \mathrm{CFU} / \mathrm{ml}$ increased from $10^{3} \mathrm{CFU}$ per blossom to $10^{5} \mathrm{CFU}$ per blossom, which was not significantly different than the mean detectable populations on blossoms treated with EhC9-1R applied at $1 \times 10^{8} \mathrm{CFU} / \mathrm{ml}$. The incidence of recovery of $E h \mathrm{C} 9-1 \mathrm{R}$ applied as lyophilized cells at $1 \times 10^{7} \mathrm{CFU} / \mathrm{ml}$ and $1 \times 10^{8} \mathrm{CFU} / \mathrm{ml}$ was similar (95 to $100 \%$ of blossoms sampled) $4 \mathrm{~h}$ after spraying. One week after inoculation, EhC9-1R was recovered from significantly fewer blossoms treated with $1 \times 10^{7} \mathrm{CFU} / \mathrm{ml}$ (33\% 'Bartlett' pear and 62\% 'Rome Beauty' apple blossoms) compared with $1 \times 10^{8} \mathrm{CFU} / \mathrm{ml}$ (79\% 'Bartlett' pear and 75\% 'Rome Beauty' apple blossoms). When EhC9-1R was sprayed as a fresh-cell inoculum preparation at a concentration of $1 \times 10^{7} \mathrm{CFU} / \mathrm{ml}$, the incidence of recovery of EhC9-1R ranged from $4 \%$ on 'Bartlett' pear blossoms and up to $50 \%$ on 'Rome Beauty' blossoms (data not shown).

Establishment of Ea153N. In 1993, inoculum preparation did not effect the incidence of recovery or the mean detectable popu-
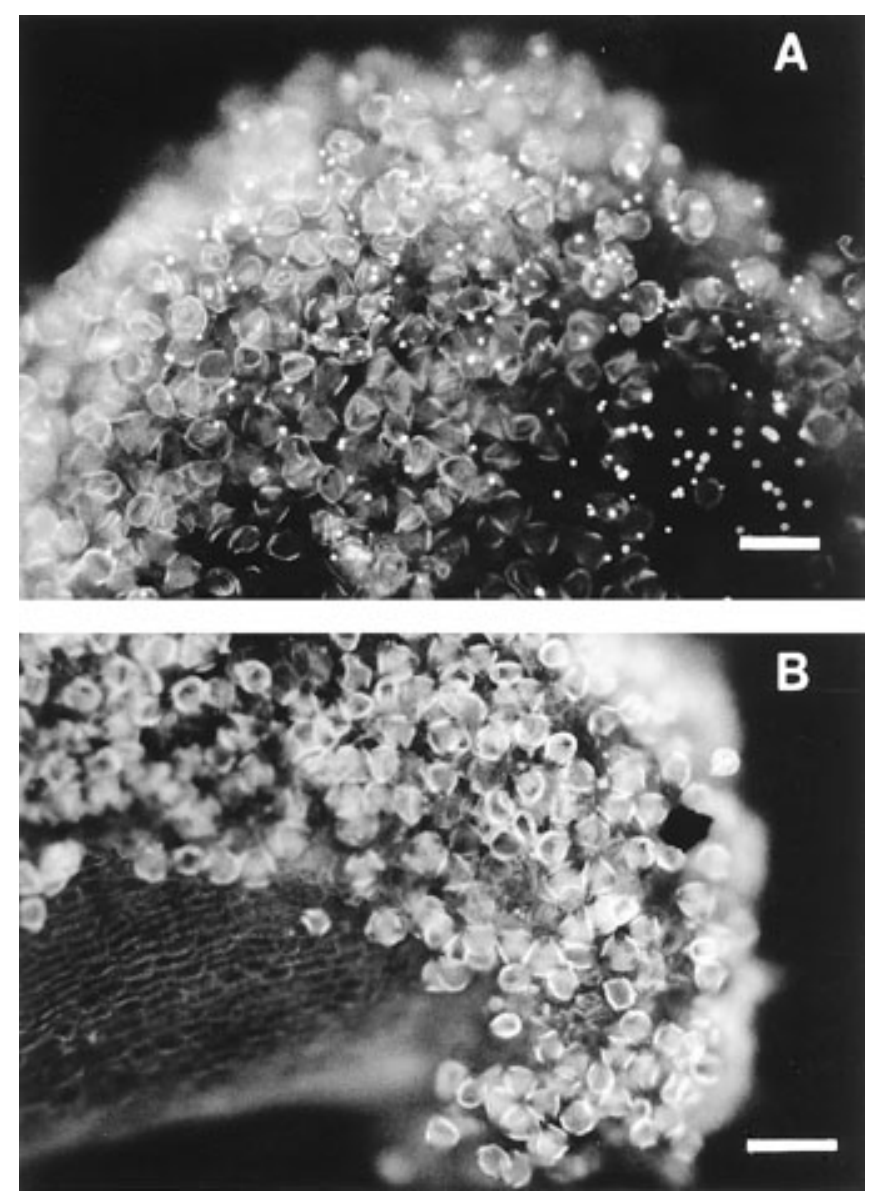

Fig. 4. A, Epifluorescence micrographs of autofluorescent microspheres (1 $\mu \mathrm{m}$ in diameter) on an apple stigma. B, Spheres were not visible on floral tissues of nontreated blossoms of apple. Bar represents $20 \mu \mathrm{m}$. lation size of $E a 153 \mathrm{~N}$ when applied at $1 \times 10^{8} \mathrm{CFU} / \mathrm{ml}$ to apple blossoms (Fig. 3A, B, F, and G). Four hours after spraying, mean detectable populations of $10^{5} \mathrm{CFU}$ per blossom were recovered from nearly every blossom inoculated. During the sampling period, Ea153N maintained statistically similar mean detectable population sizes of $10^{5}$ to $10^{6} \mathrm{CFU}$ per blossom (Fig. $3 \mathrm{~F}$ and $\mathrm{G}$ ) and was recovered from 95 to $100 \%$ of the blossoms sampled (Fig. 3A and B), regardless of the preparation of the cells sprayed onto the blossoms.

Differential establishment of fresh or lyophilized cells of Ea153N applied at an inoculum dose of $1 \times 10^{7} \mathrm{CFU} / \mathrm{ml}$ was observed in blossoms sampled from 'Bosc' pear (1993), 'Bartlett' pear (1994), and 'Rome Beauty' apple (1994). The incidence of recovery on blossoms inoculated with lyophilized cells ranged from 43 to $96 \%$, whereas the bacterium applied as fresh cells was recovered from significantly fewer blossoms (Fig. 3C to E). The mean detectable population size of Ea153N on 'Bartlett' pear and 'Rome Beauty' apple blossoms sprayed with fresh cells was significantly lower than populations established by lyophilized cells (Fig. 3I and J). On 'Bosc' pear blossoms, the mean detectable population size of $E a 153 \mathrm{~N}$ did not differ significantly between treatments 8 days after application (Fig. 3H).

Ea153N also was applied to 'Bartlett' pear and 'Rome Beauty' apple blossoms in 1994 at a concentration of $1 \times 10^{6} \mathrm{CFU} / \mathrm{ml}$. The bacterium was not recovered from blossoms treated with a freshcell preparation at $1 \times 10^{6} \mathrm{CFU} / \mathrm{ml}$ in either trial (data not shown). $E a 153 \mathrm{~N}$ also was not recovered from blossoms of 'Bartlett' pear that were inoculated with lyophilized cells at $1 \times 10^{6} \mathrm{CFU} / \mathrm{ml}$. In the 'Rome Beauty' apple trial (1994), Ea153N was recovered from 4 to $10 \%$ of the blossoms treated with lyophilized cells at $1 \times 10^{6}$ $\mathrm{CFU} / \mathrm{ml}$ (data not shown), a significantly lower incidence of recovery compared with application of lyophilized cells at a concentration of $1 \times 10^{7} \mathrm{CFU} / \mathrm{ml}$ (Fig. 3E). The mean detectable population size of Ea153N recovered from 'Rome Beauty' apple blossoms inoculated with lyophilized cells at $1 \times 10^{6} \mathrm{CFU} / \mathrm{ml}$ ranged from $2 \times 10^{2}$ to $1 \times 10^{4} \mathrm{CFU}$ per blossom during the sampling period (data not shown), which was significantly lower than the mean detectable populations recovered from blossoms inoculated with the lyophilized pathogen at $1 \times 10^{7} \mathrm{CFU} / \mathrm{ml}$ (Fig. 3J).

Detection of fluorescent microspheres on blossoms. Even after sonication, vortexing, and prolonged storage ( $>1$ year) in buffer at $4^{\circ} \mathrm{C}$, fluorescent microspheres applied to blossoms with the bacterial sprays were detected readily on floral tissues with an epifluorescence microscope (Fig. 4A). The majority of the microspheres remained attached to floral tissues under these storage conditions, but some microspheres also could be detected in the washing buffer. We did not observe samples in which microspheres were present in the wash buffer and not present in high numbers on the surfaces of the floral tissues. The relative density of microspheres from tissues harvested $4 \mathrm{~h}$ after application of bacteria was fairly uniform among individual blossom samples. The nectary surface of pear blossoms retained numerous microspheres. Within individual blossoms, each of the five styles and stigmas were coated with microspheres, although the relative density of microspheres varied from style to style.

In each of the trials, microspheres were detected on all of the treated blossoms harvested within 6 days after spraying. Microspheres were not detected on the styles or nectaries of blossoms harvested from nontreated branches (Fig. 4B). Detection of microspheres on the floral tissues confirms that all of the blossoms sampled within this time were sprayed directly with the bacterial suspensions. In three trials, blossoms were harvested 8 days after inoculation. Occasionally, one or two blossoms of the eight harvested from a replication in late bloom did not have microspheres, indicating that the blossoms were not sprayed directly with the bacterial suspension, probably because the blossoms were closed when bacteria were sprayed onto the cluster.

Environmental conditions during field experiments. From the time of inoculation to the first sample taken $4 \mathrm{~h}$ later, mean 
relative humidity ranged from 43 to $61 \%$ among field trials (Table 1). Solar radiation varied from 400 to $650 \mathrm{~J} / \mathrm{m}^{2} / \mathrm{s}$ during application of treatments (Table 1). Wind speed recorded in four of the plots was moderate, about $10 \mathrm{~km} / \mathrm{h}$. Little wind $(0.4 \mathrm{~km} / \mathrm{h})$ was recorded in the 1993 'Rome Beauty' apple plot between the time of inoculation and harvest of the first sample (Table 1). Average canopy temperatures from the time of application of bacteria to the first harvest ranged from 14 to $18^{\circ} \mathrm{C}$ (Table 1). No rain or dew was recorded for at least $8 \mathrm{~h}$ after bacterial sprays in all plots, except in the trial with 'Golden Delicious' apple in 1993 (Table 1). Approximately $1.5 \mathrm{~h}$ after application of bacteria in that trial, a light rain fell for $2.3 \mathrm{~h}$. The duration of wetness resulting from spraying was the least (9 min) in the 1994 'Bartlett' pear experiment (Table 1). The sensors remained wet for $30 \mathrm{~min}$ after inoculation in the 1993 'Rome Beauty' apple plot. In the 1993 'Golden Delicious' apple plot, the sensors did not dry before additional sensors in the canopy recorded rainfall.

Desiccation tolerance of $\boldsymbol{P f A 5 0 6}$ and $\boldsymbol{E h C 9 - 1 R}$. At $100 \%$ relative humidity, the mean population sizes of lyophilized and fresh cells of PfA506 or EhC9-1R did not differ significantly and remained stable on filter papers, which remained damp throughout the experiment (Fig. 5A and B). The mean population size of fresh cells of PfA506 was significantly lower than the population size of lyophilized cells after $3 \mathrm{~h}$ of incubation at $75 \%$ relative humidity (Fig. 5A). After $4 \mathrm{~h}$ of incubation at $75 \%$ relative humidity, the mean population size of lyophilized cells of PfA506 was significantly lower than the mean populations maintained at $100 \%$ relative humidity. By this time, the mean population size of fresh cells of PfA506 incubated at $75 \%$ relative humidity decreased by nearly $3 \mathrm{log}$ units in repeated experiments (Fig. 5A). After an incubation period of $20 \mathrm{~h}$ at $75 \%$ relative humidity, the mean population sizes of fresh and lyophilized cells of PfA506 did not differ significantly (Fig. 5A). Similar to PfA506, the mean population size of fresh cells of EhC9-1R was significantly lower than that of lyophilized cells after $3 \mathrm{~h}$ of incubation at $75 \%$ relative humidity (Fig. 5B). After $6 \mathrm{~h}$ of incubation at $75 \%$ relative humidity, the mean populations of fresh and lyophilized cells of EhC9-1R were significantly lower than the mean populations maintained at $100 \%$ relative humidity. The mean population size of fresh cells of EhC9-1R decreased by approximately $3 \log$ units after $6 \mathrm{~h}$ of incubation at $75 \%$ relative humidity, which was a significantly greater decrease in the mean population size compared with that of lyophilized cells maintained under similar conditions (Fig. 5B).

\section{DISCUSSION}

Establishment of bacterial antagonists on plant surfaces is a critical phase in disease control. Populations of antagonists established on plant surfaces are necessary for competition with pathogens for sites and nutrients and to provide a reservoir for secondary spread to tissues not colonized by the initial treatment $(11,12,15,23,33)$. We demonstrated that inoculum preparation can influence the es- tablishment of bacteria on aerial plant surfaces. The lyophilized inoculum of two bacterial antagonists and a bacterial pathogen became established on a greater proportion of blossoms than did cells harvested directly from solid media under conditions in which blossoms dried within 15 min after spraying. Differences in establishment frequently were evident at the time of the first sample, $4 \mathrm{~h}$ after treatment. When blossoms remained wet for longer periods, cells from both inoculum preparations established well.

Under conditions conducive for bacterial survival and establishment, the mean population size of bacteria recovered from blossoms for both inoculum preparations were similar, and populations of bacteria incubated at $100 \%$ relative humidity remained stable for $20 \mathrm{~h}$. This indicates that differences in nutritional composition of the inocula, i.e., skim milk and xanthan gum in the lyophilized preparation that were not present in the fresh inoculum, did not lead to detectable differences in establishment or growth of the bacteria. Prolonged moisture on the plant surface may have enhanced establishment by allowing bacteria to migrate in the water film to sites protected from desiccation and UV radiation. Others have demonstrated that mutants of $P$. syringae that lack motility establish smaller population sizes than do wild-type strains on leaves (5), presumably because they cannot move to protected sites. Furthermore, free moisture also may have allowed cell division and population size increase before conditions became nonconducive for growth and survival. In previous research on biological control of fire blight, the antagonists have, in general, established

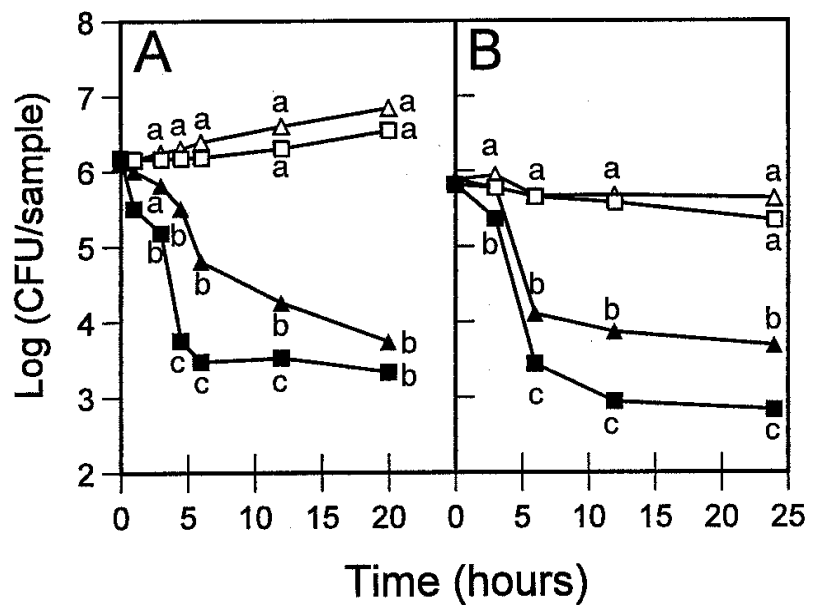

Fig. 5. Mean population sizes of A, Pseudomonas fluorescens A506 and B, Erwinia herbicola C9-1R applied as fresh cells (ם) or resuspended lyophilized cells $(\boldsymbol{\Delta})$ to filter paper and incubated at $100 \%$ (open symbols) or $75 \%$ relative humidity (solid symbols). Lower case letters represent significant differences $(P=0.05)$ in the population size among treatment means at a sample time according to Fisher's least significant difference procedure. Results from repeated experiments were similar, so representative data from one experiment for each strain is presented.

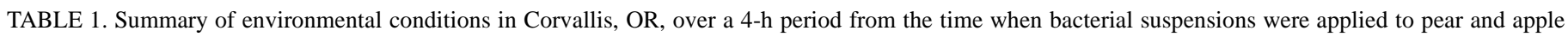
blossoms to the time of the first blossom sample

\begin{tabular}{|c|c|c|c|c|c|c|c|}
\hline Cultivar and species & Year & $\begin{array}{c}\text { Duration of } \\
\text { wetness }(\mathrm{min})^{\mathrm{a}}\end{array}$ & $\begin{array}{l}\text { Hours until natural } \\
\text { moisture event }{ }^{b}\end{array}$ & $\begin{array}{c}\text { Mean temperature } \\
\left({ }^{\circ} \mathrm{C}\right)^{\mathrm{c}}\end{array}$ & $\begin{array}{l}\text { Mean relative } \\
\text { humidity }(\%)^{\mathrm{d}}\end{array}$ & $\begin{array}{l}\text { Mean wind speed } \\
(\mathrm{km} / \mathrm{h})^{\mathrm{d}}\end{array}$ & $\begin{array}{l}\text { Mean solar radiation } \\
\left(\mathrm{J} / \mathrm{m}^{2} / \mathrm{s}\right)^{\mathrm{d}}\end{array}$ \\
\hline 'Bosc' pear & 1993 & 12 & 12 & 14.3 & 44 & 10.6 & 651 \\
\hline 'Rome Beauty' apple & 1993 & 30 & 14 & 17.9 & 61 & 0.4 & 435 \\
\hline 'Golden Delicious' apple & 1993 & $>90^{\mathrm{e}}$ & 1.5 & 16.2 & 54 & 9.6 & 485 \\
\hline 'Bartlett' pear & 1994 & 9 & 10 & 16.3 & 43 & 10.6 & 402 \\
\hline 'Rome Beauty' apple & 1994 & 16 & 8 & 17.0 & 54 & 14.3 & 628 \\
\hline
\end{tabular}

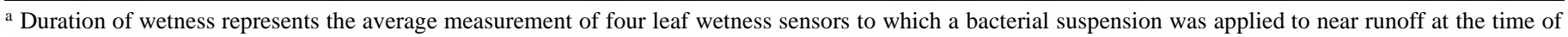
inoculation.

b Number of hours elapsed after inoculation before unsprayed leaf wetness sensors recorded a rainfall or dew event.

c Average of four temperature probes placed in the periphery of the tree canopy.

d Data obtained from a weather station located $4 \mathrm{~km}$ to the north of the experimental site.

e The leaf wetness sensors did not dry between the time that bacteria were applied and the next rainfall event. 
high populations on blossoms $(11,12,15,17,23,28)$. In some of those experiments, the bacteria were harvested from solid media and applied under calm weather at sunrise, environmental conditions that would favor slow drying of blossoms after spraying.

On the whole, aerial surfaces of plants are considered to be inhospitable to bacterial growth, because they are exposed to UV radiation, rapid changes in temperature and water availability, and coincident fluctuations in osmotic potential and nutrient availability $(3,13,14,16,24)$. As a consequence, bacteria are not distributed randomly on aerial plant surfaces, but instead are localized in cell junctures or are associated with stomates and trichomes, which provide habitats protected from full exposure to environmental stresses $(1,14)$. Bacterial cells that persist after exposure to stress are most likely those that are established in protected microsites on plant surfaces and, thus, are able to rebound when conditions become favorable for growth (35). The capacity to survive desiccation and osmotic stress are epiphytic fitness traits of $P$. syringae (16). In Escherichia coli, such phenotypic traits and others of probable significance to epiphytic survival (i.e., tolerance of UV light) are expressed preferentially by stationary-phase cells (18). Compared with actively growing cells, stationary-phase cells are relatively tolerant of certain stresses imposed under laboratory experiments $(18,25,27)$. The process of lyophilization exposes cells to stresses imposed by freezing and desiccation (4). We suggest that a stress-tolerant subset of a bacterial population survives these stresses. Alternatively, the whole population of lyophilized cells may differ physiologically from fresh cells, because of alterations imposed by the process of lyophilization. Therefore, viable cells present in lyophilized formulations may be more capable than the average bacterial cell residing on the surface of an artificial medium to survive the stresses encountered immediately upon application to plant surfaces. We examined tolerance of fresh and lyophilized cells to desiccation stress and found that lyophilized cells of EhC9-1R and PfA506 were more tolerant to drying at $75 \%$ relative humidity than were fresh cells. In the orchard, the average relative humidity ranged from 43 to $61 \%$, so differential tolerance to desiccation stress may have influenced establishment of the bacteria applied as fresh and lyophilized cells.

Enhanced survival of lyophilized cells of bacteria on plant surfaces also could be due to the presence of nonviable cells or protective materials in the inoculum preparation. Wilson and Lindow (35) showed that the addition of heat-killed cells of $P$. syringae to a bacterial suspension increased the established population size of the bacteria applied to plants maintained under arid conditions. Lyophilized preparations contain killed cells, which may contribute in part to the successful establishment of viable cells in the inoculant under stressful conditions on plant surfaces, although these killed cells and inoculant materials become relatively dilute in the spray suspension.

Cell concentration in inocula has been shown to be important in the establishment of bacteria on aerial surfaces. Wilson and Lindow (35) demonstrated in a growth chamber experiment that populations of $P$. syringae increase to the carrying capacity of leaves if the inoculum concentration is sufficient for the establishment of a single bacterium in each protected site present. We found that the incidence of establishment of lyophilized cells of bacteria on blossoms was similar when applied at concentrations of $1 \times 10^{8} \mathrm{CFU} / \mathrm{ml}$ or $1 \times 10^{7} \mathrm{CFU} / \mathrm{ml}$ and eventually achieved similar mean detectable population sizes on blossoms. Decreasing the inoculum dose of lyophilized cells of E. amylovora to $1 \times 10^{6} \mathrm{CFU} / \mathrm{ml}$ led to poor establishment, presumably because too few cells established in sites available on blossoms. When the inoculum dose of fresh cells of bacteria was decreased to $1 \times 10^{7} \mathrm{CFU} / \mathrm{ml}$, the bacteria were only recovered rarely, which was expected because the higher inoculum dose of fresh cells also established poorly. Because lyophilized cells exhibited a greater tolerance of stressful conditions on plant surfaces, the applied inoculum dose was less critical to successful colonization.
Amending inoculants with fluorescent microspheres provided a simple, qualitative control to determine if the sprayed suspension was deposited on the stigmatic surface of sampled blossoms. For example, the observed differences in the establishment of bacteria on stigmatic surfaces could be due to lack of application of the inoculum onto the stigmatic surfaces or lack of survival of the inoculant. Lack of application could result from a blossom being closed during spraying or being turned at an angle that made it less assessable to the spray inoculum. In contrast, lack of survival could be concluded because the microspheres were easily visualized on the surfaces of treated tissues with an epifluorescence microscope. Mean detectable population sizes of bacteria recovered from blossoms treated with inocula containing microspheres were similar to those obtained from previous studies in which microspheres were not included $(12,28)$; thus, the microspheres apparently do not affect establishment or growth of bacteria on stigmatic surfaces.

The bacterial antagonists EhC9-1 and PfA506 suppress fire blight of pear and apple $(12,15,17,23)$, but, like many biocontrol agents, they have not been uniformly effective in all field conditions in which they have been tested. The proportion of blossoms that support populations of these bacterial antagonists is correlated positively to their success in suppressing fire blight $(12,23)$. Therefore, methods that improve the consistent establishment of bacterial antagonists on blossoms are expected to reduce variations in the efficacy of biological control. In this study, lyophilized bacterial cells exhibited less variation in colonization of blossom surfaces under the spectrum of environmental conditions encountered in different field trials. Thus, the use of lyophilized cells of bacterial antagonists should mitigate one source of variability that has impeded the success of biological control for management of plant disease.

\section{ACKNOWLEDGMENTS}

Research was supported by the USDA Agricultural Research Service, the Oregon Agricultural Experiment Station, and the Winter Pear Control Committee. This is Oregon Agricultural Experiment Station technical paper 11,275. We thank S. Carnegie, A. Muehlchen, and T. Sawyer for excellent technical assistance and T. Paulitz and H. J. Scheck for helpful comments about the manuscript.

\section{LITERATURE CITED}

1. Beattie, G. A., and Lindow, S. E. 1994. Survival, growth, and localizations of epiphytic fitness mutants of Pseudomonas syringae on leaves. Appl. Environ. Microbiol. 60:3790-3798.

2. Beattie, G. A., and Lindow, S. E. 1994. Comparison of the behavior of epiphytic fitness mutants of Pseudomonas syringae under controlled and field conditions. Appl. Environ. Microbiol. 60:3799-3808.

3. Burrage, S. W. 1976. Aerial microclimate around plant surfaces. Pages 173-184 in: Microbiology of Aerial Plant Surfaces. C. H. Dickinson and T. F. Preece, eds. Academic Press, Inc., New York.

4. Crowe, J. H., Carpenter, J. F., Crowe, L. M., and Anchordoguy, T. J. 1990. Are freezing and dehydration similar stress vectors? A comparison of modes of interaction of stabilizing solutes with biomolecules. Cryobiology 27:219-231.

5. Haefele, D. M., and Lindow, S. E. 1987. Flagellar motility confers epiphytic fitness advantages to Pseudomonas syringae. Appl. Environ. Microbiol. 53:2528-2533.

6. Hattingh, M. J., Beer, S. V., and Lawson, E. W. 1986. Scanning electron microscopy of apple blossoms colonized by Erwinia amylovora and E. herbicola. Phytopathology 76:900-904.

7. Hirano, S. S., Clayton, M. K., and Upper, C. D. 1994. Estimation of and temporal changes in means and variances of populations of Pseudomonas syringae on snap bean leaflets. Phytopathology 84 : 934-940.

8. Hirano, S. S., and Upper, C. D. 1990. Population biology and epidemiology of Pseudomonas syringae. Annu. Rev. Phytopathol. 28:155-177.

9. Ishimaru, C., and Klos, E. J. 1984. New medium for detecting Erwinia amylovora and its use in epidemiological studies. Phytopathology 74 : 1342-1345.

10. Ishimaru, C. A., Klos, E. J., and Brubaker, R. R. 1988. Multiple antibiotic production by Erwinia herbicola. Phytopathology 78:746-750.

11. Johnson, K. B., Stockwell, V. O., Burgett, D. M., Sugar, D., and Loper, J. 
E. 1993. Dispersal of Erwinia amylovora and Pseudomonas fluorescens by honey bees from hives to apple and pear blossoms. Phytopathology 83:478-484.

12. Johnson, K. B., Stockwell, V. O., McLaughlin, R. J., Sugar, D., Loper, J. E., and Roberts, R. G. 1993. Effect of antagonistic bacteria on establishment of honey bee-dispersed Erwinia amylovora in pear blossoms and on fire blight control. Phytopathology 83:995-1002.

13. Knudsen, G. R., and Spurr, H. W., Jr. 1987. Field persistence and efficacy of five bacterial preparations for control of peanut leaf spot. Plant Dis. 71:442-445.

14. Leben, C. 1988. Relative humidity and the survival of epiphytic bacteria with buds and leaves of cucumber plants. Phytopathology 78:179-185.

15. Lindow, S. E. 1984. Integrated control and role of antibiosis in biological control of fire blight and frost injury. Pages 83-115 in: Biological Control on the Phylloplane. C. Windels and S. E. Lindow, eds. The American Phytopathological Society, St. Paul, MN.

16. Lindow, S. E., Andersen, G., and Beattie, G. A. 1993. Characteristics of insertional mutants of Pseudomonas syringae with reduced epiphytic fitness. Appl. Environ. Microbiol. 59:1593-1601.

17. Lindow, S. E., McGourty, G., and Elkins, R. 1996. Interactions of antibiotics with Pseudomonas fluorescens strain A506 in the control of fire blight and frost injury to pear. Phytopathology 86:841-848.

18. Loewen, P. C., and Henegge-Aronis, R. 1994. The role of the sigma factor $\sigma^{\mathrm{S}}(\mathrm{KatF})$ in bacterial global regulation. Annu. Rev. Microbiol. 48:53-80.

19. Loper, J. E., Henkels, M. D., Roberts, R. G., Grove, G. G., Willett, M. J., and Smith, T. J. 1991. Evaluation of streptomycin, oxytetracycline, and copper resistance of Erwinia amylovora isolated from pear orchards in Washington state. Plant Dis. 75:287-290.

20. McManus, P. S., and Jones, A. L. 1994. Epidemiology and genetic analysis of streptomycin-resistant Erwinia amylovora from Michigan and evaluation of oxytetracycline for control. Phytopathology 84:627-633.

21. Moller, W. J., Schroth, M. N., and Thomson, S. V. 1981. The scenario of fire blight and streptomycin resistance. Plant Dis. 65:563-568.

22. Norelli, J. L. 1987. Natural spread and competition between two bacterial antagonists of the fire blight pathogen, Erwinia amylovora, on blossoms of Bartlett pear. M.S. thesis. Oregon State University, Corvallis.

23. Nuclo, R. L., Johnson, K. B., Stockwell, V. O., and Sugar, D. 1998.
Secondary colonization of pear blossoms by two bacterial antagonists of the fire blight pathogen. Plant Dis. 82:661-668.

24. O'Brien, R. D., and Lindow, S. E. 1989. Effect of plant species and environmental conditions on epiphytic population sizes of Pseudomonas syringae and other bacteria. Phytopathology 79:619-627.

25. Potts, M. 1994. Desiccation tolerance of prokaryotes. Microbiol. Rev. 58:755-805.

26. Rouse, D. I., Nordheim, E. V., Hirano, S. S., and Upper, C. D. 1985. A model relating the probability of foliar disease incidence to the population frequencies of bacterial plant pathogens. Phytopathology 75:505-509.

27. Sarniguet, A., Kraus, J., Henkels, M. D., Muehlchen, A. M., and Loper, J. E. 1995. The sigma factor $\sigma^{\mathrm{S}}$ affects antibiotic production and biological control activity of Pseudomonas fluorescens Pf-5. Proc. Natl. Acad. Sci. U.S.A. 29:12255-12259.

28. Stockwell, V. O., Johnson, K. B., and Loper, J. E. 1996. Compatibility of bacterial antagonists of Erwinia amylovora with antibiotics used to control fire blight. Phytopathology 86:834-840.

29. Thomas, T. M., and Jones, A. L. 1992. Severity of fire blight on apple cultivars and strains in Michigan. Plant Dis. 76:1049-1052.

30. Thomson, S. V. 1986. The role of the stigma in fire blight infections. Phytopathology 76:476-482.

31. Van der Zwet, T., and Keil, H. L. 1979. Fire blight: A bacterial disease of rosaceous plants. Agric. Handb. (U.S. Dep. Agric. Sci. Edu. Adm.) 510.

32. Wilson, M., Epton, H. A. S., and Sigee, D. C. 1992. Interactions between Erwinia herbicola and E. amylovora on the stigma of hawthorn blossoms. Phytopathology 82:914-918.

33. Wilson, M., and Lindow, S. E. 1993. Interactions between the biological control agent Pseudomonas fluorescens A506 and Erwinia amylovora in pear blossoms. Phytopathology 83:117-123.

34. Wilson, M., and Lindow, S. E. 1993. Effect of phenotypic plasticity on epiphytic survival and colonization by Pseudomonas syringae. Appl. Environ. Microbiol. 59:410-416.

35. Wilson, M., and Lindow, S. E. 1994. Inoculum density-dependent mortality and colonization of the phyllosphere by Pseudomonas syringae. Appl. Environ. Microbiol. 60:2232-2237.

36. Wilson, M., Sigee, D. C., and Epton, H. A. S. 1989. Erwinia amylovora infection of hawthorn blossom: II. The stigma. J. Phytopathol. 127:15-28. 